\title{
M.B. EBCTPATOB
}

\section{ВОЕННЫЕ КАДРЫ И РЕПРЕССИИ 1930-Х ГОДОВ}

Ключевые слова: репрессии, военные кадры, Красная Армия, И. Сталин, командный и начальствующий состав.

В статье рассмотрен вопрос сталинских репрессий по отношению к офицерскому составу конца 1930-х г2. Выделены отдельные проблемные сюжеты, связанные с репрессиями по отношению к командно-начальствующему и политическому состава РККА. Начало массовых репрессий было положено еще в 1930-1931 г2. вследствие сфральсифицированных обвинений, связанных с делом «Весна». В статье на основе специальной исследовательской литературы раскрываются причины и последствия масштабных репрессий по отношению к военным кадрам, пик которых был связан с так называемым «заговором военных» в 1937 г. Подноготная самого заговора была определена тем, что вокруг И.В. Сталина сформировались два крупных противоборствующих лагеря из известных военных деятелей, имеющих разные взгляды на дальнейшее развитие армии. В результате «вождь» поддержал группу К.Е. Ворошилова, а сподвижники М.Н. Тухачевского были репрессированы. В статье отмечается, что около 40 тысяч человек из числа лиц командно-начальствующего состава пострадало от репрессий 1937-1938 г2. В 1939 г. по указанию «вождя» масштабный размах репрессий был сдержан. В конечном итоге среди армейских рядов были восстановлены 11178 человек. Любые взаимосвязанные события неизбежно имеют причинно-следственные связи. Многие историки, рассуждая о неудачах Советского Союза в первый год Великой Отечественной войны, приходят к выводу о том, что профессионально сложившаяся армия, приведшая к успехам в период Гражданской войны, была во многом уничтожена внутренней политикой государства, которая напрямую была связана с репрессиями конца 1930-х гг. Массовые репрессии, проведенные против командного и начальствующего состава в предвоенные годы, нанесли большой урон Красной Армии. События 1930-х ге. стали главной причиной кадровых проблем в РККА, что повлекло трагические последствия в ходе Великой Отечественной войны.

Вопрос изучения сталинских репрессий по отношению к офицерскому составу конца 1930-х гг. не является новым для исторической науки. Однако снятие грифа секретности с ряда архивных источников и выход в свет новых публикаций, отражающих разные исследовательские точки зрения ученых, позволяют обратиться к данной проблеме.

Среди ключевых аспектов проблемы репрессий по отношению к военным кадрам следует выделить конкретные сюжеты, относящиеся к карательным мерам по отношению именно к командному и начальствующему составу РККА (комначсостав). Отдельное место среди них занимают: «причины, послужившие провокацией массовых арестов и расстрелов в 1937-1939 гг.; состоятельность гипотез о "военном заговоре" и роли в его организации наиболее известных военачальников; истинные масштабы арестов и расстрелов; величина 
и тяжесть ущерба репрессий и его влияние на боеспособность Красной Армии накануне войны» [2. С. 19].

Начало массовых репрессий второй половины 1930-х гг. было связано с фральсифицированными обвинениями по делу «Весна», в результате которых с конца 1930 г. до конца 1931 г. было осуждено более 3 тыс. человек из числа командного и начальствующего состава РККА [3. С. 173].

В дальнейшем последовал приказ наркома обороны СССР от 3 фревраля 1935 г., связанный с обеспечением «соблюдения революционной законности» [7. С. 28]. В нем прописывалась непосредственно сама процедура ареста и предания суду военных кадров за совершение контрреволюционных преступлений.

Наивысший охват репрессии по отношению к военнослужащим получили во время раскрытия так называемого «заговора военных» в 1937 г. Его причина крылась в том, что в окружении И. В. Сталина сформировалось два крупных противоборствующих лагеря из известных военных деятелей, имеющих разные взгляды на дальнейшее развитие армии. В результате «вождь» поддержал группу К.Е. Ворошилова, а сподвижники М.Н. Тухачевского были репрессированы.

В период лета и осени 1937 г. репрессии получили всеармейский размах. «Уже через девять дней после суда над М.Н. Тухачевским были арестованы участники военного заговора: 980 командиров и политработников, в том числе 29 комбригов, 37 комдивов, 21 комкор, 16 полковых комиссаров, 17 бригадных и 7 дивизионных комиссаров» [4. С. 79]. Наибольшему преследованию подвергся высший командный состав: заместители наркома обороны Советского Союза, представители руководства Главных и Центральных управлений НКО, командующие военными округами, командиры корпусов, дивизий, бригад и начальники штабов всех уровней [4. С. 79].

Справедливости ради необходимо упомянуть, что в 1956 г. была проведена проверка уголовного дела М.Н. Тухачевского и многих других крупных военных деятелей, причастных к «заговору военных». Изучению подверглись материалы Главной военной прокуратуры и КГБ при Совете Министров СССР. В итоге, проанализировав документы, 31 января 1957 г. Военная коллегия Верховного Суда СССР пришла к решению: «Приговор Специального судебного присутствия Вооруженных сил СССР от 11 июня 1937 года в отношении 8 (ранее перечисленных) лиц отменить, и дело за отсутствием в их действиях состава преступления прекратить» [3. С. 175; 6. С. 31].

История вновь показывает нам, что эпохальные события связаны с борьбой за власть, в результате чего тысячи ни в чем не повинных людей были репрессированы и уволены с военной службы. В энциклопедической литературе сообщается, что итогом репрессий по делу военных стало до 36 тыс. человек [1. С. 159]. Окончательные цифровые данные репрессированных в Красной Армии до сего времени не уточнены и подвергаются спорам. Однако в исторической литературе все больше авторов приходят к мнению, что 40 тыс. человек - это то число лиц среди комначсостава, которые стали жертвами репрессий 1937-1938 гг. Впервые это число «было названо К.Е. Ворошиловым 29 ноября 1938 года на заседании Главного военного совета Красной Армии, который отмечал, что в ходе чистки Красной Армии в 1937-1938 годах мы вычистили более четырех десятков тысяч человек» [8. С. 5].

Например, справки, относящиеся к руководящим кадрам комначсостава Красной Армии за период 1937-1939 гг., свидетельствуют о многократных 
изменениях в центральном аппарате. В этих документах имеются свидетельства того, что в 1938-1939 гг. состав начальников управлений и отделов НКО был сменен на 75\%, причем в целом ряде управлений в 1937-1938 гг. руководство менялось по 2-3 раза [4. С. 86]. Командующие войсками округов в названный период сменялись по 3-5 раз; на 100\% произошла смена заместителей и помощников командующих. В 1938-1939 гг. начальники штабов округов были заменены на $100 \%$, заместители начальников штабов округов - на $75 \%$. При этом приход новых людей и их назначение на должности происходили далеко не из самых профессиональных и образованных кадров. Отметим, что рабочих и крестьян среди военных насчитывалось в 1936 г. - 32\%, в 1939 г. 82,1\%; служащих в 1936 г. - 68\%, в 1939 г. - 17,9\% [4. С. 86].

Любые взаимосвязанные события неизбежно имеют причинно-следственные связи. Многие историки, рассуждая о неудачах Советского Союза в первый год ведения Великой Отечественной войны, приходят к выводу о том, что профессионально сложившаяся армия, приведшая к успехам в период Гражданской войны, была во многом уничтожена внутренней политикой государства, которая напрямую была связана с репрессиями конца 1930-х гг. Не случайно известный исследователь Н.С. Черушев отмечает: «Один из опытных и влиятельных военных советников Гитлера - генерал-фельдмаршал Вильгельм Кейтель - на Нюрнбергском процессе показал, что некоторые немецкие генералы пытались предостеречь фрюрера от преждевременного, по их мнению, нападения на СССР, считая Красную Армию весьма сильным противником. Однако у того в конце 30-х гг. сложилось о РККА совершенно иное мнение. Он неоднократно заявлял тому же Кейтелю и другим военным чинам из своего ближайшего окружения, что первоклассный состав высших советских военных кадров истреблен Сталиным в 1937 г. Таким образом, необходимые умы в подрастающей смене еще пока отсутствуют» [8. С. 4]. Действительно, такое положение дел серьезно ослабило боеготовность Красной Армии, что подтверждали и отечественные военачальники, в частности маршал Советского Союза А.М. Василевский.

В 1939 г. по указанию «вождя» масштабный размах репрессий был сдержан. В конечном итоге среди армейских рядов были восстановлены 11178 человек, ранее уволенных или ставших жертвами репрессий по политическим и дисциплинарным причинам [3. С. 175; 5. Л. 97]. Однако массовые репрессии, проведенные против командного и начальствующего состава в предвоенные годы, нанесли большой урон Красной Армии. События 1930-х гг. стали главной причиной кадровых проблем в РККА, что повлекло трагические последствия в ходе Великой Отечественной войны.

\section{Литература и источники}

1. Великая Отечественная война. 1941-1945: энциклопедия. М.: ОЛМА-ПРЕСС, 2015. 672 c.

2. Грищенко Ю.И. Репрессии командно-начальствующего состава как фрактор ослабления боеготовности РККА (1937-1939 гг.) // Вестник Екатерининского института. 2016. № 1. С. 19-21.

3. Осьмачко С.Г. Сталинские репрессии в армии (конец 1920-х - начало 1940-х годов) // Вестник ЯВВУ ПВО. 2019. № 2. С. 172-177.

4. Печенкин А.А. Военная элита СССР в 1935-1939 гг.: Репрессии и обновление. М.: ВЗФЭИ, 2003. $172 \mathrm{c.}$

5. Российский государственный военный архив. РГВА. Ф. 33987. Оп. 3. Д. 947. 
6. Справка о проверке обвинений, предъявленных в 1937 году судебными и партийными органами тт. Тухачевскому, Якиру, Уборевичу и др. военным деятелям в измене Родине, терроре и военном заговоре // Военные архивы России. Вып. 1. М.: Пересвет; Церерес. 1993. С. 30-113.

7. Сувениров О.Ф. Наркомат обороны и наркомат внутренних дел в предвоенные годы // Вопросы истории. 1991. № 6. С. 25-35.

8. Черушев Н.С. 1937 год: Элита Красной Армии на голгофе. М.: Вече, 2003. 544 с.

ЕВСТРАТОВ МАКСИМ ВЛАДИМИРОВИЧ - адъюНКТ КафедрЫ ИсторИИ, Военный университет Министерства обороны Российской Федерации, Россия, Москва (maksim.evstratov.84@mail.ru).

\section{Maxim V. EVSTRATOV \\ MILITARY PERSONNEL AND REPRESSION OF THE 1930s}

Key words: repression, military personnel, Red Army, I. Stalin, commander and commanding staff.

The article examines the issue of carrying out Stalinist repressions against the officers of the late 1930s. Separate problematic plots associated with repressions in relation to the command and control and political composition of the Red Army are highlighted. Mass repressions began in the early 1930s. thanks to falsified charges related to the Viasna case. Based on special research literature, the article reveals the reasons and consequences of the peak of repressions against the military, which fell on the period of the disclosure of the so-called "military conspiracy" in 1937. The background of the conspiracy itself was connected with the fact that around J.V. Stalin there were two large opposing forces, consisting of eminent military men, who had different views on the further development of the army. As a result, the "leader" supported KE Voroshilov's group, and MN Tukhachevsky's associates were repressed. The article notes that about 40 thousand people from among the commanders suffered from the repressions of 19371938. In 1939, by order of JV Stalin, the mass coverage of repression was suspended, as a result, 11,178 people were reinstated in the army. Any interrelated events inevitably have a cause-and-effect relationship. Many historians, discussing the failures of the Soviet Union in the first year of the Great Patriotic War, come to the conclusion that the professionally formed army, which led to successes during the Civil War, was largely destroyed by the internal policy of the state, which was directly related to the repression of the end 1930s. The massive repressions carried out against the commanding and commanding personnel in the pre-war years inflicted great losses on the Red Army. Events of the 1930s became the main reason for personnel problems in the Red Army, which entailed tragic consequences during the Great Patriotic War.

\section{References}

1. Velikaya Otechestvennaya voina. 1941-1945: entsiklopediya [he Great Patriotic War. 1941-1945: encyclopedia]. Moscow, OLMA-PRESS Publ., 2015, 672 p.

2. Grishchenko Yu.I. Repressii komandno-nachal'stvuyushchego sostava kak faktor oslableniya boegotovnosti RKKA (1937-1939 gg.) [Repression of the commanding staff as a factor in weakening the combat readiness of the Red Army (1937-1939)]. Vestnik Ekaterininskogo instituta, 2016, no. 1, pp. 19-21.

3. Os'machko S.G. Stalinskie repressii v armii (konets 1920-kh - nachalo 1940-kh godov) [Stalinist repressions in the army (late 1920s - early 1940s)]. Vestnik YaVVU PVO, 2019, no. 2, pp. 172-177. 
4. Pechenkin A.A. Voennaya elita SSSR v 1935-1939 gg.: Repressii i obnovlenie [The military elite of the USSR in 1935-1939: Repression and renewal]. Moscow, VZFEI Publ., 2003, 172 p.

5. Rossiiskii gosudarstvennyi voennyi arkhiv. Fond 33987. Opis' 3. Delo 947 [Russian State Military Archives. Archive 33987. Anagraph 3. Document 947].

6. Spravka o proverke obvinenii, pred"yavlennykh v 1937 godu sudebnymi i partiinymi organami tt. Tukhachevskomu, Yakiru, Uborevichu $i$ dr. voennym deyatelyam $v$ izmene Rodine, terrore $i$ voennom zagovore [Certificate of verification of the charges brought against in 1937 by the judicial and party authorities, com. Tukhachevsky, Yakir, Uborevich and other military leaders in treason, terror and military conspiracy. In: Voennye arkhivy Rossii. Vyp. 1 [Military Archives of Russia. Issue 1]. Moscow, Peresvet Publ., 1993, pp. 30-113.

7. Suvenirov O.F. Narkomat oborony i narkomat vnutrennikh del $v$ predvoennye gody [People's Commissariat of Defense and People's Commissariat of Internal Affairs in the PreWar Years]. Voprosy istorii, 1991, no. 6, pp. 25-35.

8. Cherushev N.S. 1937 god: Elita Krasnoi Armii na golgofe [1937: The elite of the Red Army at Calvary]. Moscow, Veche Publ., 2003, 544 p.

MAXIM V. EVSTRATOV - Adjunct of the History Department, Military University of the Ministry of Defense of the Russian Federation, Russia, Moscow (maksim.evstratov.84@mail.ru).

Формат цитирования: Евстратов М.В. Военные кадры и репрессии 1930-х годов // Исторический поиск. 2021. - T. 2, № 3. - C. 10-14. DOI: 10.47026/2712-9454-2021-2-3-10-14. 